\title{
Correction to: Tumor $\mathrm{pH}$ and metastasis: a malignant process beyond hypoxia
}

\section{Oliver Thews ${ }^{1} \cdot$ Anne Riemann ${ }^{1}$}

Published online: 27 June 2019

(C) Springer Science+Business Media, LLC, part of Springer Nature 2019

\section{Correction to: Cancer and Metastasis Reviews https://doi.org/10.1007/s10555-018-09777-y}

The authors have noticed a typographical error in the published article. The term "epithelial-to-mesenchymal transition" should have been used instead of the term "endothelialto-mesenchymal transition" throughout the manuscript.

Publisher's note Springer Nature remains neutral with regard to jurisdictional claims in published maps and institutional affiliations.

The online version of the original article can be found at https://doi.org/ 10.1007/s10555-018-09777-y

$\triangle$ Oliver Thews

oliver.thews@medizin.uni-halle.de

1 Julius Bernstein Institute of Physiology, University of Halle-Wittenberg, Magdeburger Str. 6, 06112 Halle

(Saale), Germany 